\title{
Short communication: Species group-specific predictors at the cow and quarter level for intramammary infection with coagulase- negative staphylococci in dairy cattle throughout lactation
}

\author{
A. De Visscher, ${ }^{* 1}$ S. Piepers, ${ }^{*}$ K. Supré,† F. Haesebrouck, $\ddagger$ and S. De Vliegher* \\ *M-team and Mastitis and Milk Quality Research Unit, Department of Reproduction, Obstetrics, and Herd Health, Faculty of Veterinary Medicine, \\ Ghent University, 9820 Merelbeke, Belgium \\ †Flanders Milk Control Centre, 2500 Lier, Belgium \\ †Department of Pathology, Bacteriology, and Avian Diseases, Faculty of Veterinary Medicine, Ghent University, 9820 Merelbeke, Belgium
}

\begin{abstract}
Coagulase-negative staphylococci (CNS) are frequently isolated from quarters with subclinical mastitis, teat apices, and the cows' environment. Virulence, ecology, epidemiological behavior, and effect on udder health vary between different CNS species. Staphylococcus chromogenes, Staph. simulans, and Staph. xylosus are frequently present in milk and have a more substantial effect on quarter milk somatic cell count than other species. Therefore, these species are considered the "more relevant" CNS. As species-specific factors associated with CNS intramammary infection (IMI) have not yet been identified and susceptibility for IMI differs between cows and quarters, this study aimed to identify predictors for CNS IMI at the cow and quarter level (some of them changing over time) with a specific focus on the aforementioned more relevant CNS. Precise data were available from a longitudinal study $(3,052$ observations from 344 quarters from 86 dairy cows belonging to 3 commercial dairy herds). All CNS were molecularly identified to the species level, and multivariable, multilevel logistic regression models taking into account the longitudinal nature of the data, were fit to study the likelihood of infection. Staphylococcus chromogenes, Staph. xylosus, and Staph. cohnii were the most frequently isolated species from CNS IMI in older cows, whereas Staph. chromogenes, Staph. xylosus, and Staph. simulans were the main species found in IMI in heifers. Quarters from heifers (as opposed to multiparous cows), from heifers and multiparous cows in third or fourth month in lactation (as opposed to early lactation, $<60 \mathrm{~d}$ in milk), and with an increasing quarter milk SCC were more likely to be infected with the more relevant CNS species. Quarter milk SCC was identified as the sole statistically significant predictor for IMI with other CNS species, although the size of the effect
\end{abstract}

Received November 10, 2014.

Accepted April 14, 2015.

${ }^{1}$ Corresponding author: Anneleen.Devisscher@UGent.be was lower [odds ratio of $1.6(1.4-1.9)$ vs. $2.1(1.8-2.5)$ ] than the effect for IMI with the more relevant CNS. As a strong herd effect was present, studying herd-level predictors is warranted.

Key words: predictors, coagulase-negative Staphylococcus species, intramammary infection

\section{Short Communication}

Coagulase-negative staphylococci are the most frequently isolated bacteria from subclinical mastitis cases in dairy cows (Makovec and Ruegg, 2003; Piepers et al., 2007; Sampimon et al., 2009a). In addition, they are abundantly present in the cows' environment (Piessens et al., 2011) and on their teat apices (Taponen et al., 2008; Braem et al., 2012). Several factors associated with CNS-group IMI have been identified (Sampimon et al., 2009a; Piepers et al., 2011) but in none of the studies were CNS accurately identified to the species level and one study included only heifers. As speciesspecific differences in protective effects, (presumed) virulence, antimicrobial resistance, persistence, and effect on udder health have been revealed (Sampimon et al., 2011; Vanderhaeghen et al., 2014, 2015), studying CNS as a group is no longer recommended. Rather, accurate species-level studies or studies at the subgroup level, when analyses at the species level are hindered by small numbers, are needed.

Intramammary infection with Staphylococcus chromogenes, Staph. simulans, and Staph. xylosus is associated with a more pronounced increase in SCC compared with other species (Supré et al., 2011; Fry et al., 2014), suggesting that these species have a more substantial effect on udder health and are, for that reason considered more relevant than others. Differences in susceptibility for CNS IMI between cows and quarters exist as some cows in a specific herd have no CNS infected quarters whereas others have multiple quarters infected with CNS (Piessens et al., 2011; Supré et al., 2011), indicating that the likelihood of infections is explained not only by CNS traits but also by host factors. 
The aim of this study was to identify cow- and quarter-level predictors for IMI throughout lactation caused by the more relevant CNS species for udder health, Staph. chromogenes, Staph. simulans, and Staph. xylosus, as well as other species.

Data were obtained from a longitudinal study conducted between September 2007 and January 2009 in 3 commercial dairy herds in Flanders (Belgium). On all farms, cows were housed in freestall barns with cubicles with sawdust bedding and a concrete slatted floor. Postmilking teat disinfection and blanket dry cow therapy combined with application of an internal teat sealant were applied. Detailed herd information can be found elsewhere (Supré et al., 2011; De Visscher et al., 2014). Single quarter milk samples were aseptically collected every month for determining quarter milk SCC (qSCC) and for bacteriological culturing. Several potential cow- and quarter-level predictors were recorded at each sampling occasion, some of them changing over time (observation level, lowest level of the data set; Table 1). Animals with a test-day milk yield $\geq 33.35$ $\mathrm{kg} / \mathrm{d}$ (i.e., the median value of all test-day records of all animals) were defined as high producing, whereas animals with a test-day milk yield $<33.35 \mathrm{~kg} / \mathrm{d}$ were defined as low producing. Stage in lactation was categorized as described by Zadoks et al. (2001): $1=1-60$ DIM; $2=61-120$ DIM; $3=121-180$ DIM; $4=>180$ DIM. Body condition score of each animal was scored on a 5-point scale divided into quarter-point increments as described by Edmonson et al. (1989). Recoding was applied for further analyses $(1=\leq 2.5 ; 2=2.5-3.5 ; 3=$ $\geq 3.5)$. The teat skin and teat apex condition were determined based on a 9-point scale visual scoring system (De Vliegher et al., 2003) and recoded (0 = without cracks; 1 = with cracks). Quarter milk SCC was determined at the Flanders Milk Control Centre (Lier, Belgium) using a Fossomatic 5000/FC (Foss Electric, Hillerød, Denmark). Bacteriological culturing of all milk samples was performed following National Mastitis Council guidelines (Hogan et al., 1999). All CNS were identified to the species level using transfer RNA intergenic spacer PCR (tDNA-PCR; Supré et al., 2009) and IMI status was assigned based on subsequent samplings as described by Supré et al. (2011). Staphylococcus chromogenes, Staph. simulans, and Staph. xylosus were considered CNS species with a more substantial effect on udder health (Supré et al., 2011; Fry et al., 2014) and referred to as "more relevant" species throughout the paper; all other CNS species originating from milk in this study are referred to as "less relevant" species. Before statistical analysis was conducted, observations were revised and checked for unlikely values. Complete data were available from 344 quarters from 86 cows, making 3,052 observations in total. Logistic mixed regression models were fit in SAS 9.3 (SAS Institute Inc., Cary, NC). Clustering of observations occurred at multiple levels. Repeated observations were clustered in time within quarters, whereas quarters within cows and cows within herds were spatially clustered. For those reasons, analyses were run with herd and sampling forced into all models as fixed effects and quarter as random effect (REPEATED statement). Cow as random effect was omitted because of nonconvergence of the models when combined with a quarter random effect. The contribution of each of the random effects was estimated (VARCOMP procedure) and revealed that quarter accounted for more variability than cow (Zadoks et al., 2001). Compound symmetry was used as the covariance structure for within-quarter correlation (Barkema et al., 1997; Zadoks et al., 2001). Two different binary outcome variables at the quarter level were used: (1) IMI with the more relevant CNS, and (2) IMI with the less relevant CNS, both versus being noninfected. Initially, univariable associations were tested between the 2 binary outcome variables and all predictor variables at the cow, quarter, and observation level. Statistical significance in this step was assessed at $P<0.15$. Second, Spearman correlation coefficients were calculated among all statistically significant predictor variables to check for multicollinearity. If 2 predictor variables had a correlation coefficient $\geq 0.60$, only one was selected for further analyses. In the third step, multivariable models were fit for the 2 outcome variables using backward stepwise elimination. Statistical significance in this step was assessed at $P<0.05$. Interaction terms were tested between all remaining statistically significant predictors. The goodness-offit of the final models was evaluated by plotting the observational-level standardized residuals against the observational-level predicted values.

On average, 53 lactating cows were present in the herds (range $=39-70$ ) with an average of 29 animals per herd being included in the study, resulting in a total of 3,052 analyzed milk samples. One hundred twentyeight IMI with the more relevant CNS and 48 IMI with the less relevant CNS were available for analysis. Overall, Staph. chromogenes caused most IMI ( $\mathrm{n}=83 ; 47 \%$ of all IMI) followed by Staph. xylosus ( $\mathrm{n}=28 ; 16 \%)$, Staph. cohnii ( $\mathrm{n}=19 ; 11 \%)$, Staph. simulans $(\mathrm{n}=17$; 10\%), Staph. haemolyticus $(\mathrm{n}=11 ; 6 \%)$, and Staph. fleurettii $(\mathrm{n}=6 ; 3 \%)$. Sixty-nine percent $(\mathrm{n}=121)$ of all CNS IMI $(n=176)$ originated from quarters of cows in second or higher lactation. However, only $0.07 \%$ of all quarters of older cows were infected with CNS, whereas $16.4 \%$ of all quarters of heifers were infected. The majority of CNS IMI from quarters of heifers $(93 \%, \mathrm{n}=$ $50)$ and multiparous cows $(64 \%, \mathrm{n}=77)$ were caused by the more relevant species. Staphylococcus simulans 
Table 1. Overview of all potential cow-, quarter-, and observation-level predictor variables (independent variables)

\begin{tabular}{|c|c|c|c|}
\hline Independent variable & Recording method & Description & Breakdown of categories in final model \\
\hline \multicolumn{4}{|l|}{ Cow level } \\
\hline Breed & DHI records & Two breeds & Black and white $\mathrm{HF}^{1}$ vs. red and white $\mathrm{HF}$ \\
\hline \multicolumn{4}{|l|}{ Quarter level } \\
\hline \multicolumn{4}{|l|}{ Observation level } \\
\hline Parity $^{2}$ & DHI records & Parity at test-day & First lactation vs. second lactation or older \\
\hline Milk yield ${ }^{3}$ & DHI records & Milk yield at test-day & Low $^{4}(<33.35 \mathrm{~kg})$ vs. high $(\geq 33.35 \mathrm{~kg})$ \\
\hline Quarter milk SCC ${ }^{6}$ & Fossomatic $5000 / \mathrm{FC}^{7}$ & Quarter SCC at test-day & Continuous \\
\hline Teat skin condition ${ }^{6}$ & Visual and palpation & Nine-point scale ${ }^{8}$ & Without cracks vs. with cracks \\
\hline Teat apex condition ${ }^{6}$ & Visual and palpation & Nine-point scale ${ }^{8}$ & Without cracks vs. with cracks \\
\hline
\end{tabular}

${ }^{1}$ Holstein Friesian.

${ }^{2}$ Cow-level variable potentially changing during the study.

${ }^{3}$ Cow-level variable changing during the study.

${ }^{4}$ Categorization based on median value of all test-day records of all cows.

${ }^{5}$ Edmonson et al. (1989).

${ }^{6}$ Quarter-level variable changing during the study.

${ }^{7}$ Foss, Hillerød, Denmark.

${ }^{8}$ De Vliegher et al. (2003).

was mainly isolated from IMI in quarters of heifers $(82 \%, \mathrm{n}=14)$. Coagulase-negative staphylococci IMI in quarters of multiparous cows were most frequently caused by Staph. chromogenes $(43 \%, \mathrm{n}=52)$, Staph. xylosus $(18 \%, \mathrm{n}=22)$, and Staph. cohnii $(15 \%, \mathrm{n}=$ 18). Staphylococcus chromogenes $(56 \%, \mathrm{n}=31)$, Staph. simulans $(26 \%, \mathrm{n}=14)$ and Staph. xylosus $(11 \%, \mathrm{n}=$ $6)$ were the majority of CNS IMI in quarters of heifers. Overall, CNS species were equally collected in any stage of lactation. Staphylococcus chromogenes (71\%, n $=12)$, Staph. haemolyticus $(12 \%, \mathrm{n}=2)$, Staph. xylosus $(12 \%, \mathrm{n}=2)$, and Staph. sciuri $(6 \%, \mathrm{n}=1)$ were the only species causing IMI in the first 2 mo after parturition (1 to $60 \mathrm{DIM})$. The more relevant CNS species were mostly isolated from IMI in quarters of heifers in a later stage of lactation (>180 DIM), whereas IMI in quarters of older cows caused by those relevant species were equally present in any stage in lactation. Most of the less relevant CNS $(\mathrm{n}=36,77 \%)$ were isolated from IMI in quarters with a qSCC $<200,000$ cells $/ \mathrm{mL}$, whereas for the more relevant CNS, this was only $45 \%$.

A first reduction based on the univariable models revealed 5 and 4 predictor variables associated with IMI $(P<0.15)$ with more relevant CNS and less relevant CNS, respectively (Table 2). As no correlation coefficient $\geq 0.6$ between the statistically significant predictors was calculated, all independent variables were added in the multivariable models.

The final multivariable, multilevel models are presented in Table 3. Quarters from heifers (as opposed to multiparous cows), from heifers and multiparous cows in third or fourth month in lactation (as opposed to early lactation, $<60$ DIM), and with an increasing qSCC were more likely to be infected with the more relevant CNS. Quarter SCC was identified as the sole statistically significant predictor for IMI with other CNS species, although the size of the effect was lower [odds ratio of 1.6 (1.4-1.9) compared with $2.1(1.8-2.5)$ ] than for IMI with the relevant species. None of the tested interaction terms was significant. Statistically significant herd effects (herd forced in all models to correct for clustering of cows within herds) for both IMI with the more and less relevant CNS species, respectively, were present.

This is to our opinion, the first study identifying CNS group-specific predictor variables in a longitudinal setting using precise molecular techniques for CNS speciation. Before the current study, past investigations examined factors associated with CNS IMI, but researchers either did not differentiate CNS species or used inaccurate phenotypic identification methods (Sampimon et al., 2009b). Several studies demonstrated a high prevalence of CNS around calving. Still, to our knowledge, in none of the other studies was the prevalence of CNS IMI in early lactation compared with the prevalence of CNS IMI later in lactation.

We confirmed that heifers were more likely to be infected with (relevant) CNS compared with multiparous cows (Sampimon et al., 2009a). Quarters from heifers and cows in peak lactation (61-120 DIM) were more likely to be infected with the more relevant species despite applying postmilking teat disinfection and using dry cow antibiotics in all 3 herds. This might support the assumption of CNS being able to develop resistance 
Table 2. Univariable mixed logistic regression models ${ }^{1}$ for IMI with CNS considered more ${ }^{2}$ or less relevant for udder health

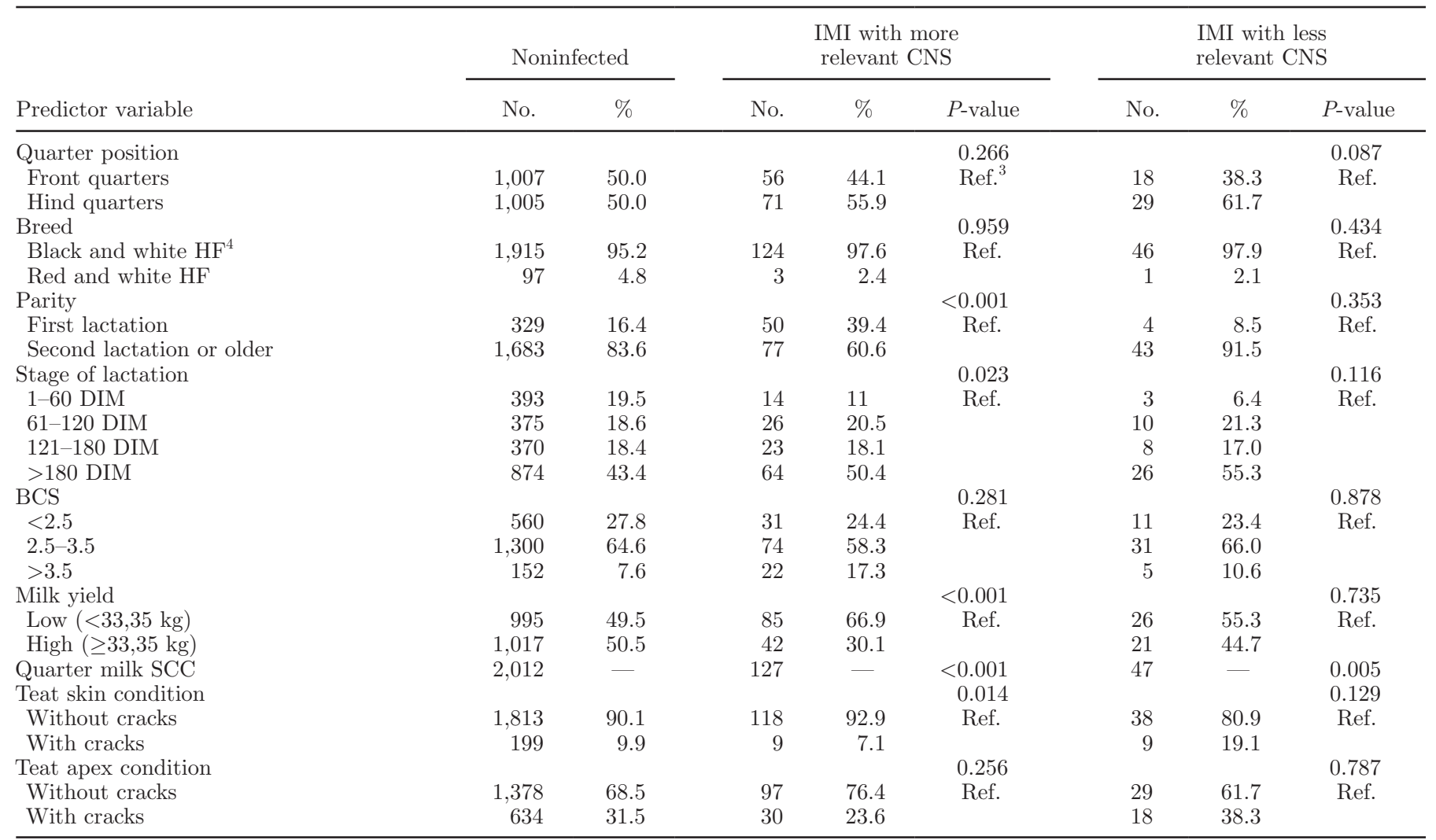

${ }^{1}$ Herd and sampling were forced into all models as fixed effects to correct for potential clustering of cows within herds and for multiple observations per quarter, respectively.

${ }^{2}$ Staphylococcus chromogenes, Staph. simulans, and Staph. xylosus.

${ }^{3}$ Reference category per predictor variable.

${ }^{4}$ Holstein Friesian.

to antibiotics and teat disinfectants (Sampimon et al., 2011; Piessens et al., 2012).

A high proportion of the variation in the likelihood of CNS IMI was observed at the quarter level, which is in agreement with the findings of another study conducted by our group (Passchyn et al., 2014). This probably relates to the fact that cows are more likely to be infected with CNS than with major pathogens and that some cows are infected with CNS in 1 quarter, whereas others harbor CNS in up to 4 quarters at the same time (Makovec and Ruegg, 2003; Piepers et al., 2007; Sampimon et al., 2009a). In contrast, other studies (also) dealing with major pathogens such as Staphylococcus aureus and Streptococcus uberis observed that a higher proportion of the variation in the outcome resided at the cow level (Zadoks et al., 2001; Passchyn et al., 2014).

More statistically significant predictors for IMI caused by the more relevant CNS were identified than for IMI with the less relevant CNS. The greater number of isolates of relevant CNS species in the dataset likely explains this, although we hypothesize that it also reflects differences in virulence and host adaptation.

On farms with excellent udder health, reflected by a bulk milk SCC $<200,000$ cells/mL, CNS infections may be an important contributor to the total number of somatic cells in the bulk milk (Schukken et al., 2009). In addition, a high proportion of cows infected with the more relevant CNS might result in an unwarranted increase in the bulk milk SCC in such a herd, also because IMI with the more relevant CNS last longer, on average, than IMI with the less relevant CNS (Supré et al., 2011). We hypothesize that our data are useful for selecting quarters and cows infected with the more relevant CNS in herds in which major pathogens are not an issue. The results suggest that focus should be on quarters with an elevated qSCC from heifers and on heifers and multiparous cows in peak lactation (61-120 DIM). In addition, molecular techniques able to identify CNS at the species level or at least able to distinguish the more relevant from the less relevant CNS would be very valuable when making individual cow-level decisions in 
DE VISSCHER ET AL.

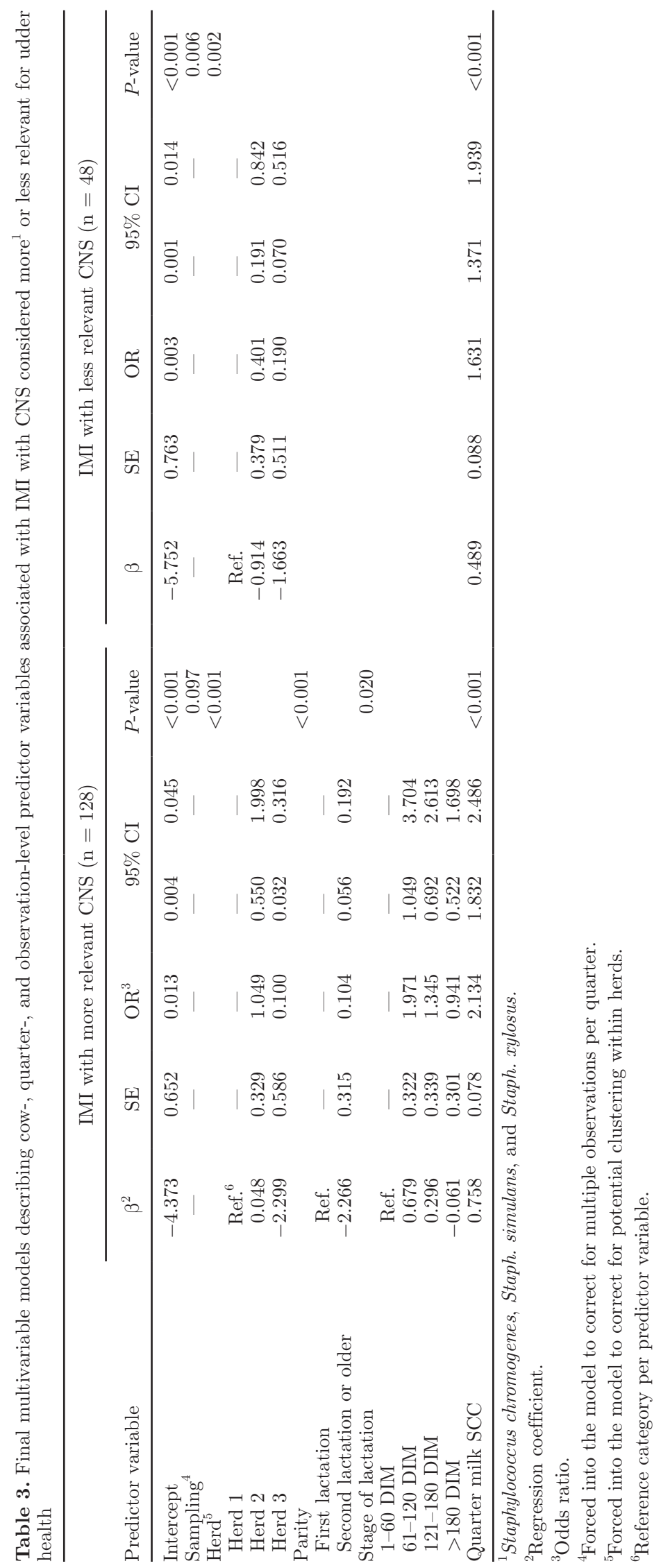


those herds. As statistically significant differences were observed between herds in likelihood of CNS infection, species-specific analysis at the herd level is required. This implies setting up studies that include large numbers of herds based on quarter milk samples from an even larger number of cows. Using bulk milk samples to identify herd-level predictor variables for IMI with the more relevant CNS could be helpful to circumvent this inconvenience and should be investigated.

\section{REFERENCES}

Barkema, H. W., Y. H. Schukken, T. J. G. M. Lam, D. T. Galligan, M. L. Beiboer, and A. Brand. 1997. Estimation of interdependence among quarters of the bovine udder with subclinical mastitis and implications for analysis. J. Dairy Sci. 80:1592-1599.

Braem, G., S. De Vliegher, B. Verbist, M. Heyndrickx, F. Leroy, and L. De Vuyst. 2012. Culture-independent exploration of the teat apex microbiota of dairy cows reveals a wide bacterial species diversity. Vet. Microbiol. 157:383-390.

De Visscher, A.. K. Supré, F. Haesebrouck, R. N. Zadoks, V. Piessens, E. Van Coillie, S. Piepers, and S. De Vliegher. 2014. Further evidence for the existence of environmental and host-associated species of coagulase-negative staphylococci in dairy cattle. Vet. Microbiol. 172:466-474. http://dx.doi.org/10.1016/j.vetmic.2014.06.011.

De Vliegher, S., L. Laevens, H. W. Barkema, G. Opsomer, T. Hemling, and A. de Kruif. 2003. Short-term effect of transition from conventional to automated milking on teat skin and teat end condition. J. Dairy Sci. 86:1646-1652.

Edmonson, A. J., I. J. Lean, L. D. Weaver, T. Farver, and G. Webster. 1989. A body condition scoring chart for Holstein dairy cows. J. Dairy Sci. 72:68-78.

Fry, P. R., J. R. Middleton, S. Dufour, J. Perry, D. Scholl, and I. Dohoo. 2014. Association of coagulase-negative staphylococcal species, mammary quarter milk somatic cell count, and persistence of intramammary infection in dairy cattle. J. Dairy Sci. 97:4876-4885.

Hogan, J. S., R. N. González, R. J. Harmon, S. C. Nickerson, S. P. Oliver, J. W. Pankey, and K. L. Smith. 1999. Laboratory Handbook on Bovine Mastitis. Rev. ed. National Mastitis Council, Madison, WI.

Makovec, J. A., and P. L. Ruegg. 2003. Results of milk samples submitted for microbiological examination in Wisconsin from 1994 to 2001. J. Dairy Sci. 86:3466-3472.

Passchyn, P., S. Piepers, and S. De Vliegher. 2014. Pathogen groupspecific risk factors for intramammary infection in treated and untreated dairy heifers participating in a prepartum antimicrobial treatment trial. J. Dairy Sci. 97:6260-6270. http://dx.doi. org/10.3168/jds.2014-8119.

Piepers, S., L. De Meulemeester, A. de Kruif, G. Opsomer, H. W. Barkema, and S. De Vliegher. 2007. Prevalence and distribution of mastitis pathogens in subclinically infected dairy cows in Flanders, Belgium. J. Dairy Res. 74:478-483.

Piepers, S., K. Peeters, G. Opsomer, H. W. Barkema, K. Frankena, and S. De Vliegher. 2011. Pathogen group specific risk factors at herd, heifer and quarter levels for intramammary infections in early lactating dairy heifers. Prev. Vet. Med. 99:91-101.

Piessens, V., S. De Vliegher, B. Verbist, G. Braem, A. Van Nuffel, L. De Vuyst, M. Heyndrickx, and E. Van Coillie. 2012. Characterization of coagulase-negative Staphylococcus species from cows' milk and environment based on bap, icaA, and mecA genes and phenotypic susceptibility to antimicrobials and teat dips. J. Dairy Sci. 95:7027-7038.

Piessens, V., E. Van Coillie, B. Verbist, K. Supré, G. Braem, A. Van Nuffel, L. De Vuyst, M. Heyndrickx, and S. De Vliegher. 2011. Distribution of coagulase-negative Staphylococcus species from milk and environment of dairy cows differs between herds. J. Dairy Sci. 94:2933-2944.

Sampimon, O. C., H. W. Barkema, I. M. G. A. Berends, J. Sol, and T. J. G. M. Lam. 2009a. Prevalence and herd-level risk factors for intramammary infection with coagulase-negative staphylococci in Dutch dairy herds. Vet. Microbiol. 134:37-44.

Sampimon, O. C., T. J. G. M. Lam, D. J. Mevius, Y. H. Schuken, and R. N. Zadoks. 2011. Antimicrobial susceptibility of coagulasenegative staphylococci isolated from bovine milk samples. Vet. Microbiol. 150:173-179.

Sampimon, O. C., R. N. Zadoks, S. De Vliegher, K. Supré, F. Haesebrouck, H. W. Barkema, J. Sol, and T. J. G. M. Lam. 2009b. Performance of API Staph ID 32 and Staph-Zym for identification of coagulase-negative staphylococci isolated from bovine milk samples. Vet. Microbiol. 136:300-305.

Schukken, Y. H., R. N. González, L. L. Tikofsky, H. F. Schulte, C. G. Santisteban, F. L. Welcome, G. J. Bennet, M. J. Zurakowski, and R. N. Zadoks. 2009. CNS mastitis. Nothing to worry about? Vet. Microbiol. 134:9-14.

Supré, K., S. De Vliegher, O. C. Sampimon, R. N. Zadoks, M. Vaneechoutte, M. Baele, E. De Graef, S. Piepers, and F. Haesebrouck. 2009. Technical note: Use of transfer RNA-intergenic spacer PCR combined with capillary electrophoresis to identify coagulase-negative Staphylococcus species originating from bovine milk and teat apices. J. Dairy Sci. 92:3204-3210.

Supré, K., F. Haesebrouck, R. N. Zadoks, M. Vaneechoutte, S. Piepers, and S. De Vliegher. 2011. Some coagulase-negative Staphylococcus species affect udder health more than other. J. Dairy Sci. 94:2329-2340

Taponen, S., J. Björkroth, and S. Pyörälä. 2008. Coagulase-negative staphylococci isolated from bovine extramammary sites and intramammary infections in a single dairy herd. J. Dairy Res. 75:422429

Vanderhaeghen, W., S. Piepers, F. Leroy, E. Van Coillie, F. Haesebrouck, and S. De Vliegher. 2014. Invited review: Effect, persistence, and virulence of coagulase-negative Staphylococcus species associated with ruminant udder health. J. Dairy Sci. 97:5275-5293.

Vanderhaeghen, W., S. Piepers, F. Leroy, E. Van Coillie, F. Haesebrouck, and S. De Vliegher. 2015. Identification, typing, ecology and epidemiology of coagulase-negative staphylococci associated with ruminants. Vet. J. 203:44-51. http://dx.doi.org/10.1016/j. tvjl.2014.11.001.

Zadoks, R. N., H. G. Allore, H. W. Barkema, O. C. Sampimon, G. J. Wellenberg, Y. T. Gröhn, and Y. H. Schukken. 2001. Cow and quarter-level risk factors for Streptococcus uberis and Staphylococcus aureus mastitis. J. Dairy Sci. 84:2649-2663. 